Kevin L. Kliesen is an economist and William Poole is the president of the Federal Reserve Bank of St. Louis. This article is adapted from a speech by William Poole to the 2000 ASU Agriculture-Business Conference Agriculture 2000: Issues and Alternatives, February 16, 2000. Tom Pollmann provided research assistance.

\section{Agriculture Outcomes and Monetary Policy Actions: Kissin' Cousins?}

\author{
Kevin L. Kliesen \\ and William Poole
}

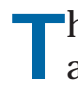
he topic of the impact of monetary policy on agriculture is an old one, and one subject to a lot of misinformation. ${ }^{1}$ The misinformation arises because too few understand that most of what goes on in agriculture has nothing to do with monetary policy. Monetary policy, more or less, involves the process by which policymakers manage-as best they can-the amount of money and credit they create for the economy-otherwise known as financial liquidity. By contrast, the fundamental forces that shape the agricultural industry-forces that determine the behavior of prices and outputare a consequence of nonmonetary conditions. Nevertheless, monetary policymakers are called upon periodically to influence outcomes in the farm sector through "easier" monetary conditions. In fact, messing up monetary policy by diverting it from its primary objective of achieving price stability will only make agricultural conditions more difficult.

The chief focus of this article is on the supply and demand conditions in agriculture. The first section contains an analysis of recent trends in farm incomes and their inherent volatility. The next two sections cover the particular conditions of supply and demand in agricultural markets. Combining supply and demand conditions leads to an analysis of outcomes for price and output. Following this analysis, we then compare and contrast the agricultural sector with computer manufacturing, another industry characterized by rapid productivity growth and falling prices.

With the analysis of the economic fundamentals of agriculture in hand, we then can discuss the specifics of monetary policy and what, if anything, policymakers can do to mitigate periodic adverse developments down on the farm. The main message is this: The Federal Reserve needs to concentrate on its primary responsibility of keeping inflation low and stable. Achieving sustained low inflation requires that interest rates sometimes rise and sometimes fall. Although interest-rate fluctuations can cause problems in agriculture, there is no other known way to keep inflation low and stable. Furthermore, compromising monetary policy objectives will not help agriculture in the end, but will actually make things worse by generating instability in the inflation rate, interest rates, and the level of economic activity.

\section{INCOME VOLATILITY IN AGRICULTURE}

As nearly everyone knows-including most of those engaged in the business of food and feed production-the United States is currently in the midst of a record-breaking business expansion: 109 months and counting as of April 2000. Nearly as remarkable, the current expansion follows on the heels of the 92-month-long expansion in 198290 , and is more than twice as long as the average of all post-World War II business expansions. Moreover, these two expansions were separated by one of the mildest recessions in U.S. history. Professor John Taylor, a distinguished economist at Stanford University, has dubbed the 17-year period since 1982 "The Long Boom." 2 Since 1982, the output of U.S. final goods and services-or real GDP-has nearly doubled, growing at an average annual rate of almost 3.75 percent per year. By contrast, real GDP grew at about 2.25 percent per year from 1972 to 1982, a period wracked by two severe economic downturns and high and rising inflation.

It thus appears, as Taylor and others have argued, that a case can be made that improved monetary policy has played an important role, though certainly not the only role, in achieving this long period of sustained economic growth at a healthy pace. Whatever else might have been going on, the rate of consumer price index (CPI)

\footnotetext{
${ }^{1}$ See Francis (1974).

${ }^{2}$ See Taylor (1998).
} 


\section{Figure 1}

\section{Real Net Farm Income, 1910-98}

\section{Billions}

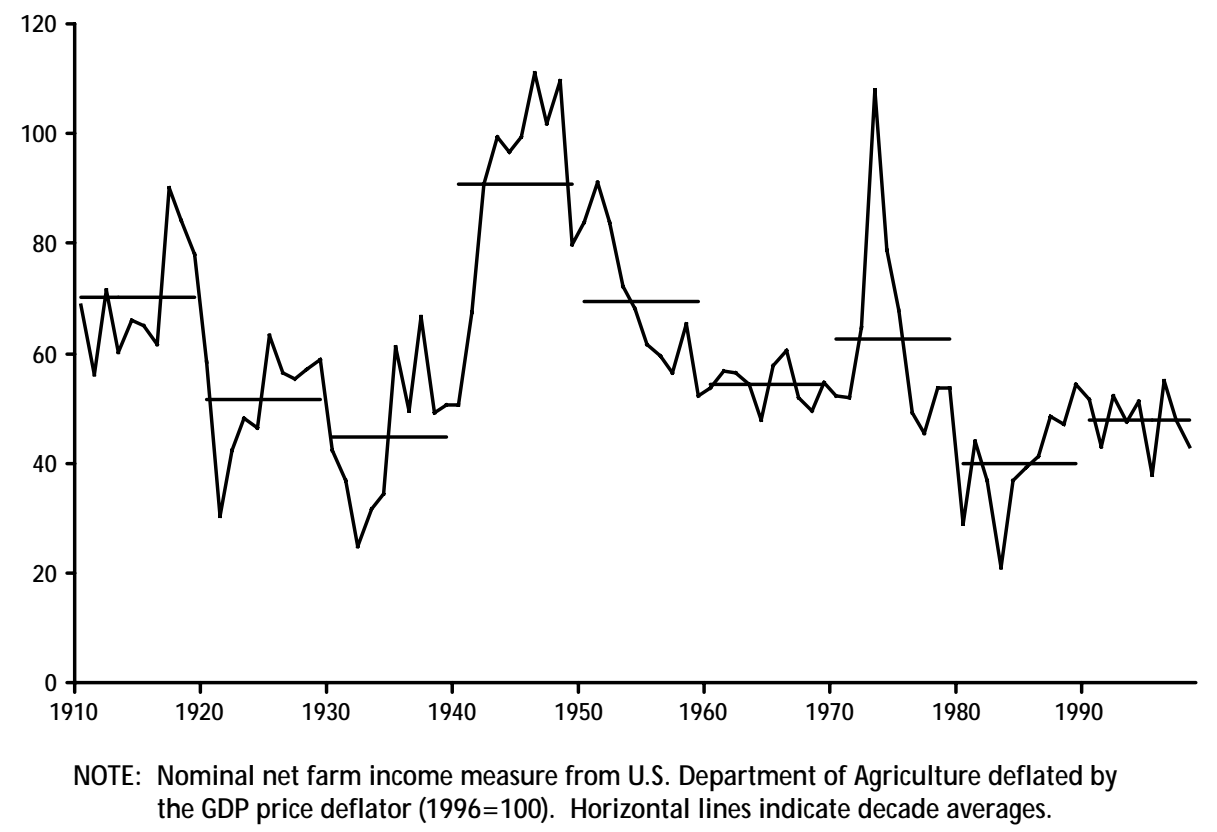

inflation could not have declined from more than 13 percent in 1980 to 2.7 percent over the 12 months ending December 1999 if the Federal Reserve had not concentrated its efforts on controlling inflation. In fact, inflation variability during the current business expansion is the lowest of all previous post-World War II expansions. ${ }^{3}$ By sharply reducing the rate of price inflation and establishing firm expectations in the marketplace that inflation would remain low, monetary policy has contributed to higher productivity growth and enhanced the economy's stability.

In general, the current business expansion has bestowed numerous benefits for virtually every demographic group in the United States. ${ }^{4}$ Still, even though the U.S. unemployment rate has fallen from about 11 percent at the end of 1982 to 4 percent in early 2000 , we know that some members of our society have been left behind. Many of those in farming and ranching will respond to these words by thinking, "Yes, many of us in agriculture have been left behind." Indeed, the last couple of years have been rough for U.S. agriculture
But agriculture always has been a risky and uncertain business. In ancient times, farmers suffered from droughts and locusts. Today, farmers still suffer from droughts and locusts. In addition, ancient farmers suffered not only from natural hazards but also from market disruptions brought on by war, the edicts of emperors, and other manmade problems. When viewed in this context, it is not surprising that income volatility is an endemic characteristic of farming.

This characteristic is illustrated nicely by changes in farm incomes during the 1990s. After rising to a 21-year high of $\$ 54.9$ billion in 1996, real, or inflation-adjusted, net farm income subsequently fell 13 percent in 1997 and roughly another

\footnotetext{
3 Inflation variability is measured as the standard deviation of the quarterly CPI inflation rates. The standard deviation of inflation during the current expansion is about three-quarters of a percentage point, compared to roughly 2-percentage points during the 1982-90 expansion, about 3.5-percentage points during the 1975-80 expansion and 2.5-percentage points during the 1970-73 expansion.

${ }^{4}$ See Poole and Wall (2000).
} 
10.5-percent in 1998. Although the latest projections from the U.S. Department of Agriculture (USDA) suggest that some improvement occurred in 1999, this upswing most likely will have stemmed entirely from a nearly $\$ 11$ billion jump in government income transfers to farmers. For a longer-term perspective, as seen in Figure 1, consider that real net farm income averaged $\$ 47.7$ billion between 1990 and 1998, roughly 20 percent more than the $\$ 39.8$ billion annual average seen during the 1980 s.

The early 1990s, then, were not so bad, but farm income during those years pales next to the $\$ 62.6$ billion average real net farm income during the 1970s. The tumultuous 1970s, frankly, were an unusual decade. Some of agriculture's good fortune for that period was purchased at the cost of severe problems in the 1980s. Although farm incomes during the 1970s rose rather sharply for a few yearsreal net farm income jumped from $\$ 52$ billion in 1971 to $\$ 108$ billion only two years later-this surge was the result of several unsustainable factors, such as the United States allowing the Soviets to enter the U.S. market to buy every bushel of corn, wheat, and soybeans they could get their hands on. But by 1980, against the backdrop of high and rising inflation, high and rising interest rates and a depreciating dollar, real farm income had plummeted to $\$ 29$ billion. Just three years later, it plunged another 27 percent to $\$ 21$ billion. By 1983, real net farm income was more than 80 percent lower than it had been just a decade earlier and even lower than the \$25-billion low point reached during the depths of the Depression in 1932.

Many specific factors account for sharp swings in farm income. Many of these factors, which have been well chronicled in the literature, will be discussed below in the context of changes in supply and demand over time ${ }^{5}$ Suffice to say, it seems clear that the rising farm incomes during the 1970s, which were boosted largely by a sharp rise in exports, helped to fuel an outbreak of speculative behavior by farmers, ranchers, and investors to counter the corrosive effects of high and rising inflation. As the real price of U.S. farmland soared, so did farm debt. The resulting financial imbalances that built up during the 1970s, not surprisingly, were unsustainable.

Because farming is an inherently risky business, swings in farm incomes over time can be, have been, and probably will continue to be, quite dramatic. Is there something inherently unstable in agricultural production-that is, beyond normal variations in weather or, perhaps, macro-policy mistakes-that contributes to these swings in farm incomes over time? The answer, to be blunt, is no. The basic characteristics of agricultural product markets that contribute to trends in farm incomes over time, it turns out, are readily explainable within the context of an analysis that looks at the basics of supply and demand conditions, the interaction of which determines prices and quantities of agricultural products.

\section{SUPPLY CONDITIONS IN AGRICULTURE}

In terms of sheer producing power per unit of input, American agriculture ranks as an unqualified success. The average U.S. farmer is growing and harvesting more now than he has at any time in history-and he's doing it, in the aggregate, with fewer inputs. Indeed, for 100 years or more, U.S. agriculture has been characterized by fantastic productivity advances. A closer look at this productivity explosion reveals some startling statistics. During the past 75 years, the number of acres harvested for corn grain has declined by 16 percent while production has increased five-fold. Similarly, while cotton production in recent years is little changed from 1926, when cotton acreage peaked at just under 45 million acres, yields per acre have more than tripled while the number of acres harvested has fallen by more than two-thirds. And it's not just crop producers who have become more productive The number of cattle and calves peaked at around 132 million in 1975. Since then, the cattle inventory has dropped by about a quarter while meat production has increased 11.5 percent. Likewise, the number of pounds per broiler produced has risen from roughly three in 1950 to nearly five today.

In the aggregate, accordingly, the amount of output produced by each farmer, including farm employees, has risen from almost \$2,300 in 1910 to roughly $\$ 35,600$ in 1998 -or a little more than 3 percent a year. ${ }^{6}$ (These figures, including the real net farm income measure cited earlier, are in constant dollars, with a base year of 1996.) Much of this

\footnotetext{
${ }^{5}$ See Belongia (1986) and the references cited therein.

${ }^{6}$ Real farm output series calculated at the Federal Reserve Bank of St. Louis using previously published BEA data. The denominator in the farm output per worker series is the Average Number of Farm Workers on Farms, and was obtained from the National Agricultural Statistics Service (NASS).
} 
increase has occurred since 1973, a period when productivity in the nonfarm sector began to slow dramatically. From 1973 to 1998, the amount of farm output per worker rose at an average annual rate of nearly 5 percent per year. In contrast, the productivity growth in the nonfarm business sector during this period measured 1.5 percent a year.

That the industry has been able to increase production with fewer farmers and ranchers is testament to the tremendous benefits gleaned from technological innovations. Doane's Agricultural Report recently ranked those innovations that have contributed to agriculture's tremendous productivity advances during the 20 th century. ${ }^{7}$ In Doane's view, research and education, mechanization, hybrid seed corn, commercial fertilizers and chemical pesticides were the top five improvements. Most economists probably would concur with these assessments. But just as the new technologies associated with the computer, the Internet, lasers, and telecommunications have revolutionized many aspects of the nonagricultural economy, more innovations are on the way which, if developed properly, promise even greater advances in agricultural productivity in the future.

The advent of genetically modified organisms in many crops, which follows the advances in genetic improvements applied to livestock production, promises both increased production and reduced reliance on pesticides. Likewise, the use of satellite technology to better apportion fertilizer and other soil nutrients, combined with the increased usage of low-till farming, offer the promise of increased production with reduced chemical fertilizer applications. Some of these technological innovations are controversial. But these controversies are a whole other subject. What needs to be emphasized is that productivity improvement in agriculture is a great American triumph, and understanding it is essential to understanding the basics of agricultural markets.

A useful way to summarize this discussion is to envision the usual upward-sloping supply curve with a big arrow on it, pointing to the right, to indicate that the entire supply curve is shifting out rapidly over time as productivity improvements accumulate. But since supply bounces around from year to year depending on growing conditions-the droughts and the locusts-it also is necessary to envision a couple of dashed supply curves parallel to the solid one.

\section{Demand Conditions in Agriculture}

The second half of the Marshallian scissors is the demand curve. The demand for agricultural products, like other "normal" goods, of course, slopes down. For our purposes, though, the relevant questions are how steep is it and how does it move over time?

Let's start with the movement over time. The demand for food rises as the population rises and as the average income of consumers rises. The effect of rising income has been understood for a long time. In the mid-19th century, Prussian economist Ernst Engel put forth the proposition that the more income you have, the smaller the fraction of your income spent on food. This proposition was so well established that it became known as "Engel's Law." The demand for food products, therefore, increases proportionately with population, but increases more slowly than does per-capita income For example, if per-capita income rises by 3 percent in real terms, the percentage increase in demand for food products would be considerably less-perhaps only 1 percent. In the United States and other high-income countries, we observe the consistent pattern that expenditures on farm commodities grow more slowly than total expenditures. Thus, expenditures on farm commodities decline relative to the economy as a whole.

Engel's law can be seen graphically in Figure 2, which shows U.S. food expenditures as a share of total expenditures from 1929 to $1999 .{ }^{8}$ During the Depression years, and extending into World War II, when per-capita real income growth was relatively weak, consumption of food as a share of total expenditures rose from about 25 percent to nearly 35 percent. But as real income growth picked up after World War II, expenditures on food as a share of total consumption expenditures fell, reaching about 14 percent in 1999.

The market for U.S. agricultural production is not, of course, limited to U.S. consumers. The United States, by virtue of its abundant natural

\footnotetext{
7 “Doane's Focus Report," Doane's Agricultural Report, Dec. 31, 1999, pp. 5-6.

8 At the present time, the Bureau of Economic Analysis had yet to release its revised NIPA measures back to 1929; the data are only available from 1959 to 1999. Accordingly, the calculated food expenditure share is based on the unrevised data. However, the food expenditure share for 1959 is equivalent for both revised and unrevised data, which suggests that data revisions will have little, if any, effect on the calculated share.
} 


\section{Figure 2}

\section{Food Expenditures as a Share of Total Consumer Expenditures}

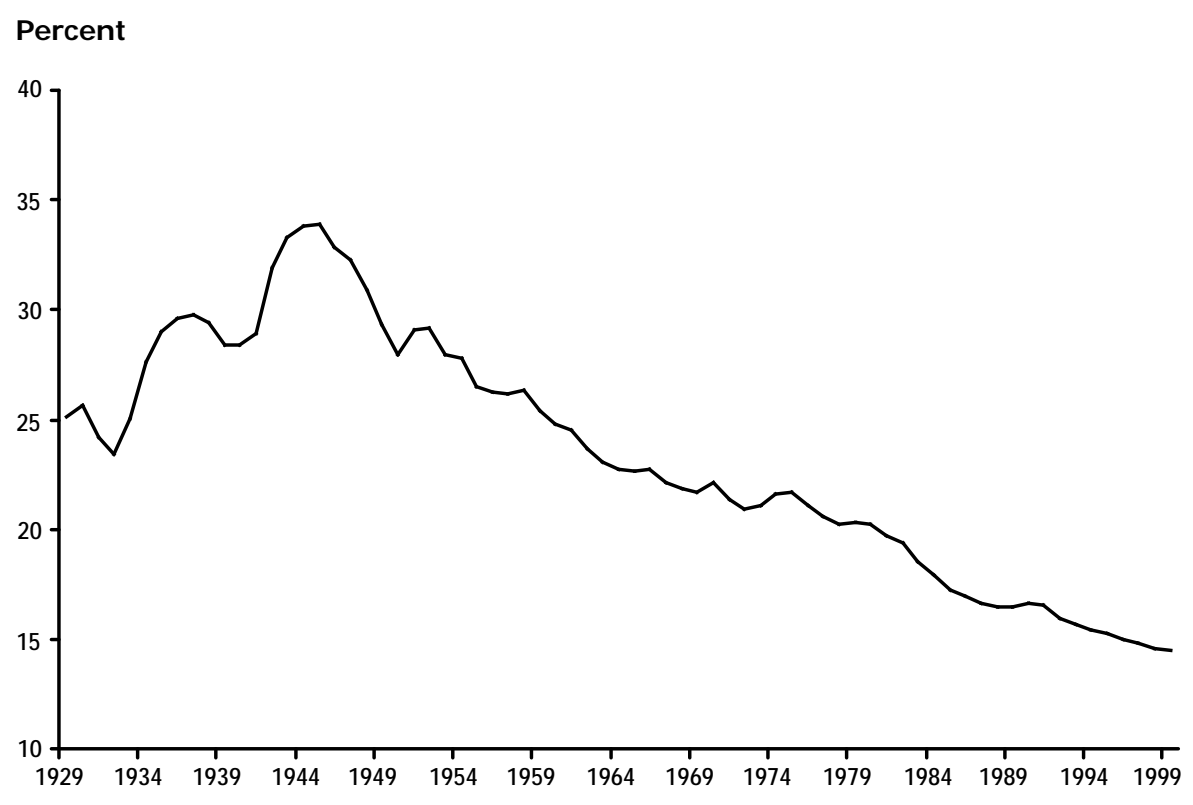

NOTE: See footnote 8

resources and plentiful supply of capital, enjoys a distinct comparative advantage in agriculture production relative to most other countries. Given the limited upside to boosting the domestic demand for farm products, one way to increase sales of U.S. farm products is to make them available to consumers in other parts of the world. And, in fact, the share of U.S. farm production that is exported has steadily trended up over time. From 1935 to 1954, U.S. farm exports averaged 8.5 percent of total farm output. This share reached a high of 28 percent in 1980 and has averaged roughly 25 percent since 1988 (see Figure 3). As important as exports are to U.S. producers, the reality is that food demand around the world is subject to Engel's Law, which means that world demand for U.S. farm output is unlikely to grow rapidly. Moreover, as the recent Asian crisis showed, unexpected demand disturbances from foreign markets are a fact of life. It is probably true, then, that export demand-welcome though it certainly is-is more volatile than domestic demand.

What about the shape of the demand curve for food? This analysis can be very brief. Americans, or, by extension, consumers in most high-income countries, don't consume very much more food when its price declines_or, equivalently, very much less when its price increases. We can thus summarize the demand conditions this way: The demand curve for agricultural products is quite steep, shifts out only gradually over time, and is somewhat volatile because export demand is volatile. The demand curve on our imaginary chalkboard, in other words, is pretty steepinelastic, in economists' lingo.

\section{Supply and Demand Together- Price and Output Trends in Agriculture}

In any market, price and quantity are determined by the interaction of supply and demand. The long-run outcome in agriculture is dominated by the fact that the supply curve, driven by rapid productivity improvement, is shifting out more rapidly than the demand curve. Thus, agricultural prices-relative to prices in general-have been trending down. Indeed, farm prices have been falling relative to nonfarm prices for as long as we 


\section{Figure 3}

\section{U.S. Farm Exports as a Share of Farm Output}

\section{Percent}

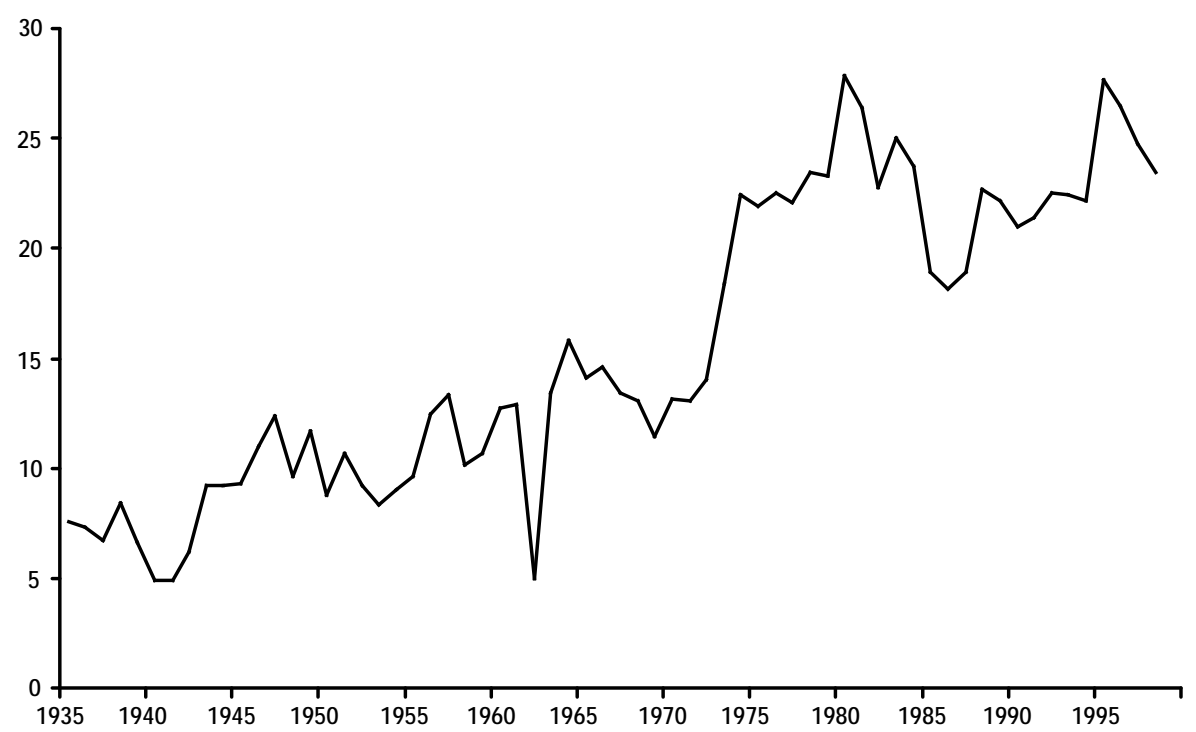

SOURCE: U.S. Department of Agriculture

can measure them. This fact is shown in Figure 4, which plots the ratio of the implicit price deflator for farm output to the total GDP implicit price deflator $(1996=100)$. From 1909 to 1941, farm price increases trailed aggregate price increases by about three-quarters of a percentage point a year. That margin doesn't sound very large, but maintained for 30 years, it cuts the relative price of agricultural prices by 21 percent. There was a brief interval during World War II and its immediate aftermath when farm prices shot up dramatically, largely owing to production constraints during the War and the subsequent surge in foreign demand from war-ravaged countries. From 1941 to 1948, farm prices advanced at roughly 14.5 percent a year, while aggregate prices rose a little more than 7.5 percent a year.

The historical trends reasserted themselves shortly thereafter, as farm prices subsequently resumed their downward trend. The waves of technological innovations noted earlier ramped up production, causing supply growth to outstrip demand growth. Even though U.S. living standards rose in the aftermath of World War II, Engel's Law remained in force and food demand grew relatively slowly. From 1948 to 1998, relative farm prices declined by roughly 3 percent a year; by 1998, the relative price of food was 78 percent below its 1948 level. Falling relative farm prices, in turn, caused farm income to grow more slowly than nonfarm income.

Farm output has been growing in absolute terms, but less rapidly than output of all goods taken together. Modest agricultural output growth is a direct outcome of the fact that the U.S. population has been pretty well fed for a long time, and does not choose to eat that much more even when the price of food goes lower. The bottom line, in terms of long-term trends, is that agricultural prices have been falling and total output rising only modestly.

The inevitable outcome of rapid technological advance and slow growth of total demand is that the demand for workers in agriculture declines. It seems rather unfair that an especially innovative and productive sector such as agriculture tends to 


\section{Figure 4}

\section{Ratio of U.S. Farm Prices to Prices of all Goods and Services}

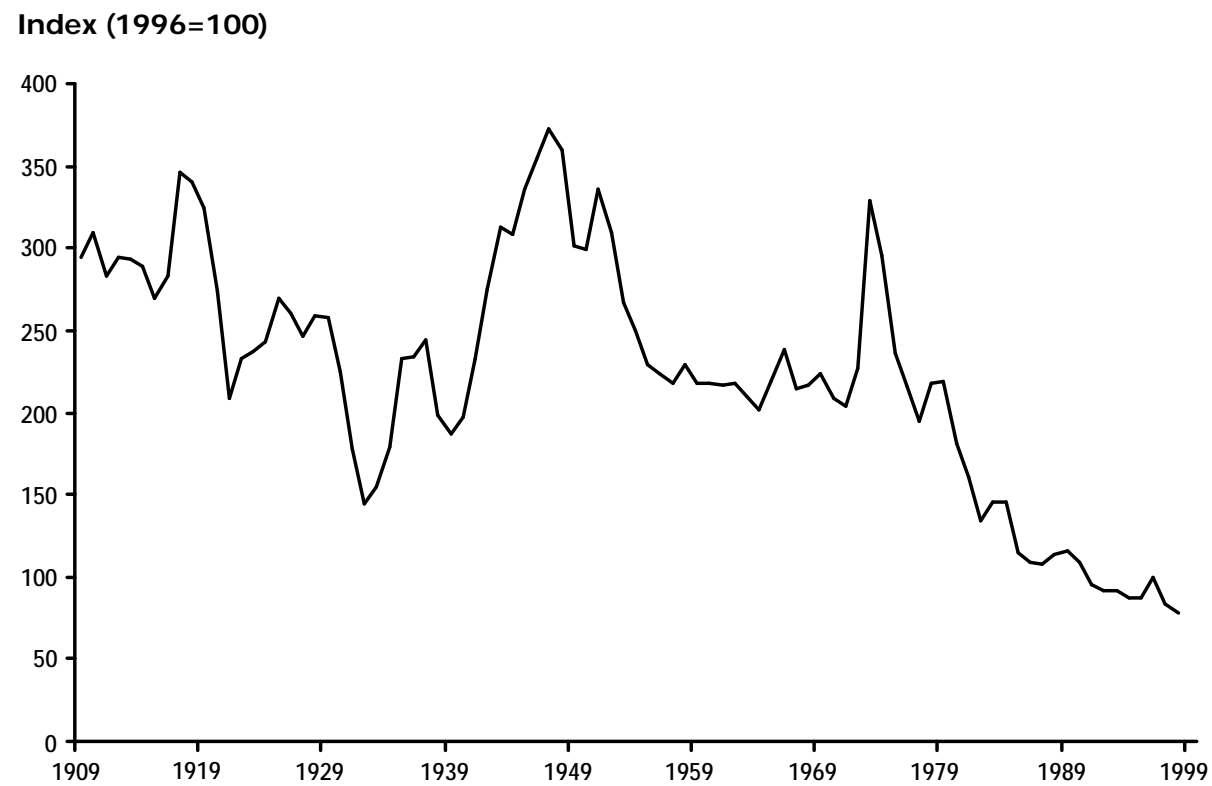

SOURCE: U.S. Department of Agriculture and the Federal Reserve Bank of St. Louis

generate low incomes. In particular, income prospects are especially bleak for those in agriculture who fall behind the cutting edge of technological improvement. In the words of the economist Hendrik Houthakker, "The greater the increase in farm productivity, the greater the imbalance between supply and demand of farm products which has to be corrected by an outflow of labor or by lower farm prices." Moreover, Houthakker notes that "unless the outflow of labor from farming is fast enough, an increase in farm productivity leads only to lower farm prices and lower farm incomes." How low incomes go depends on how rapidly workers move out of agriculture to industries with better income prospects. While the deck appears stacked against those engaged in farming and ranching-and this analysis may seem rather brutal - the fact is that low incomes are driven by the inexorable economic forces of high productivity growth, slow demand growth, and insufficiently rapid exit of workers from agriculture.

Consider the following numbers. From 1910 to 1932, U.S. farm employment declined modestly, from 13.6 million to 12.8 million, or about 0.25 percent per year. ${ }^{10}$ During the 1930s, labor outflows accelerated markedly and continued largely unabated until roughly 1987, when farm employment total ed just under 3 million, or about a quarter of what it was 50 years earlier. Persistent labor outflows from the farming sector, naturally, means that farm employment will steadily decline as a share of total employment, as is shown in Figure 5. In 1999, farm employment was about 2 percent of total employment, whereas in 1900 about 41 percent of civilian employees were engaged in farm employment. ${ }^{11}$

It appears that the major adjustment in the number of agricultural workers is now over. Since 1987, farm employment has stabilized, and even

\footnotetext{
9 See Houthakker (1967), p. 7.

${ }^{10}$ Average Number of Farm Workers on Farms, National Agricultural Statistics Service (NASS).

${ }^{11}$ See Economic Report of the President (2000), Table B-33, page 346, and U.S. Department of the Census (1978).
} 


\section{Figure 5}

\section{Agricultural Employment as a Share of Civilian Employment and Real Farm Output as a Share of Real GDP}

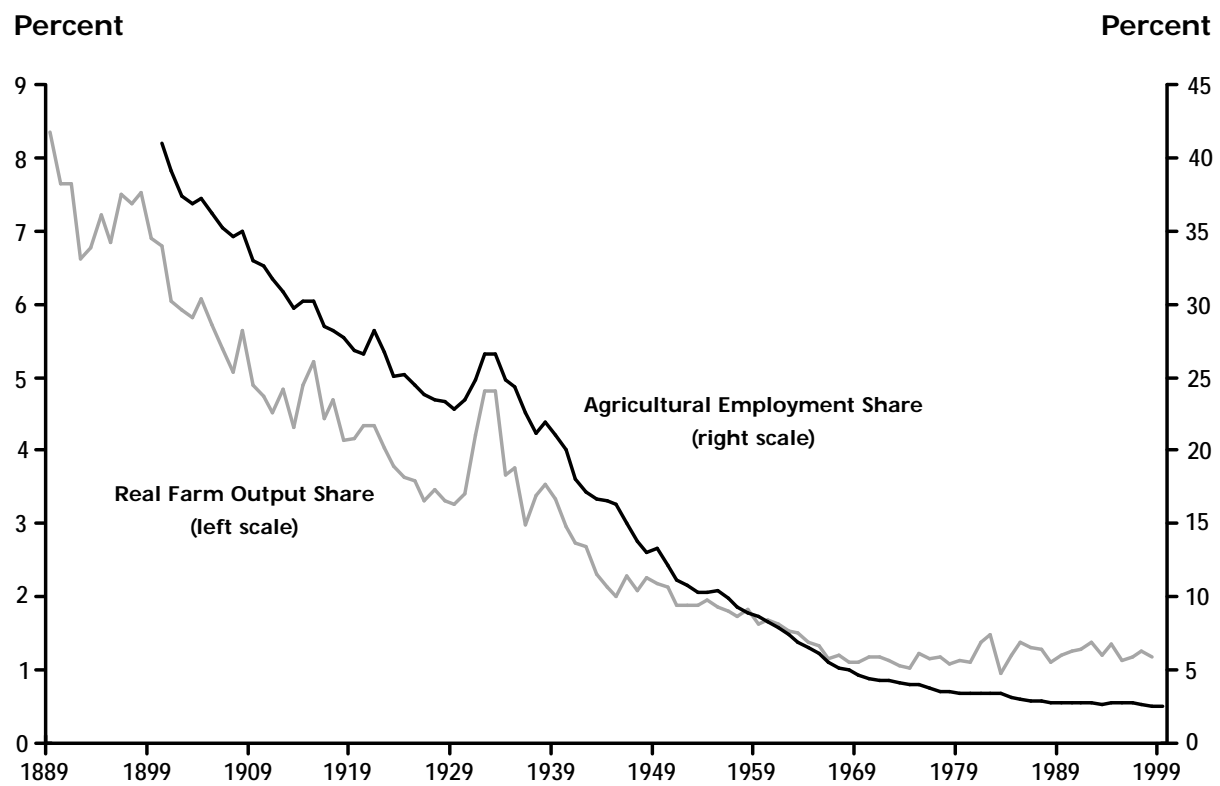

SOURCE: U.S. Department of Commerce and the Federal Reserve Bank of St. Louis

risen slightly. Of course, farm employment continues to fall as a share of total employment but the most difficult period in which a large absolute decline occurred is now past.

Another way to see the extent to which productivity gains have ratcheted up farm output over time is by examining the growth of all inputs, not just labor input. Table 1 shows that the index of total farm output increased by roughly 135 percent from 1948 to 1996 (the latest observation), or a little more than 1.75 percent per year. ${ }^{12}$ Over this period, though, the index of total farm input-a measure designed to capture the influence of intermediate inputs like fertilizer, fuel, labor, and capital-actually declined. What is interesting is that nearly all of this decline in input stems from reductions in labor input. Whereas inputs of intermediate products rose 84 percent and capital input rose 33 percent, labor input dropped 70 percent, or approximately 2.5 percent per year.

Although farm output has increased substantially over time, it has not kept pace with growth in the nonfarm sector of the economy. As seen in
Figure 5, from 1889 to 1966, real farm output as a percent of total GDP declined from nearly 8.5 percent to about 1.25 percent. Since then, it has remained fairly constant, implying that the rate of return to agriculture has more or less stabilized at its long-run rate. The continued existence of inefficient farms, though, suggests that other factors are keeping some resources in the industry that might well earn a higher return elsewhere.

Now is the time to put our chalkboard to work. This Marshallian dance is depicted in Figure 6. As noted earlier, both the supply (S) and demand (D) curves for agriculture are fairly inelastic, something that has been known to agricultural economists for quite some time ${ }^{13}$ The supply and demand curves are dancing around, sometimes creating large and painful declines in prices, and sometimes delightful increases in prices-delight-

\footnotetext{
12 The index values in this paragraph are found in the Economic Report of the President (2000), Tables B-97 and B-98, pp. 418-19.

${ }^{13}$ See Gardner (1992).
} 


\section{Table 1}

\section{Growth of Farm Productivity, Inputs, and Output}

\begin{tabular}{|c|c|c|c|}
\hline Compound Annual Rates of Change & 1948-73 & 1973-96 & $1948-96$ \\
\hline Total Farm Output & 1.85 & 1.78 & 1.81 \\
\hline Total Livestock Output & 1.99 & 1.33 & 1.67 \\
\hline Total Crop Output & 1.72 & 2.00 & 1.86 \\
\hline Total Farm Inputs & 0.20 & -0.41 & -0.09 \\
\hline Farm Labor & -3.01 & -1.91 & -2.48 \\
\hline Farm Real Estate & 0.30 & -0.41 & -0.04 \\
\hline Durable Equipment & 3.03 & -1.67 & 0.75 \\
\hline Energy & 1.35 & 0.25 & 0.82 \\
\hline Fertilizer & 3.09 & -0.73 & 1.24 \\
\hline Pesticides & 10.37 & 2.70 & 6.63 \\
\hline Farm Labor Productivity & 5.09 & 3.80 & 4.47 \\
\hline Farm Multifactor Productivity & 1.64 & 2.19 & 1.90 \\
\hline \multicolumn{4}{|l|}{ Addenda: } \\
\hline Nonfarm Business Sector Productivity ${ }^{1}$ & 1.67 & 1.47 & 2.00 \\
\hline Nonfarm Business Sector Multifactor Productivity & 1.89 & 0.21 & 1.08 \\
\hline
\end{tabular}

ful for producers, anyway. The dance sometimes yields painful declines in output-the years of droughts and locusts-and sometimes enormous bumper crops. And these fluctuations occur on top of long-run trends characterized by declining prices and modestly rising output. The long-run trend is illustrated in Figure 6 by the fact that the supply curves, $\mathrm{S}_{1}$ to $\mathrm{S}_{4}$, increase proportionately more than the demand curves, $D_{1}$ to $D_{4}$, across time

\section{AGRICULTURE AND COMPUTER INDUSTRIES COMPARED}

It is interesting to compare agriculture with the computer industry-another industry characterized by high productivity growth. Though the two industries are vastly different in terms of their output, the qual itative nature of their labor input, and the production processes they employ, the computer and agriculture industries do share a couple of key characteristics. First, the two are both capital intensive. Second, the prices of their outputs con- tinue to fall relative to the prices of all other goods and services. In fact, unlike farm prices, personal computer prices have actually fallen in absolute terms since they entered the marketplace. Since 1978 , computer prices have fallen by an average of 17 percent per year, while prices for all output, as measured by the GDP chain price deflator have risen by about 3.75 percent per year. Thus, the relative price of computers has declined by more than 20 percent per year-much more, recall, than the 3-percent per-year drop in relative agricultural commodity prices. Why are computer firms getting rich while farmers face the threat of bankruptcy?

In both agriculture and computer manufacturing, supply conditions are dominated by rapid productivity improvement. But demand conditions in the two industries are very different. In fact, computer output has risen much faster than aggregate output. While the demand for farm commodities is relatively insensitive to price and income changes, the demand for personal computers is not. In terms of basic supply and demand analysis, the 
Figure 6

\section{Supply and Demand Conditions in Agriculture}

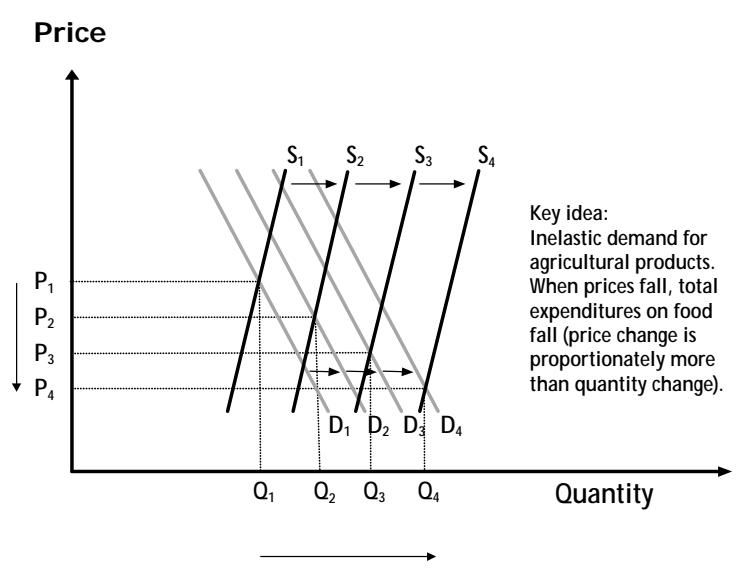

Figure 7

\section{Supply and Demand Conditions in the Computer Industry}

Price

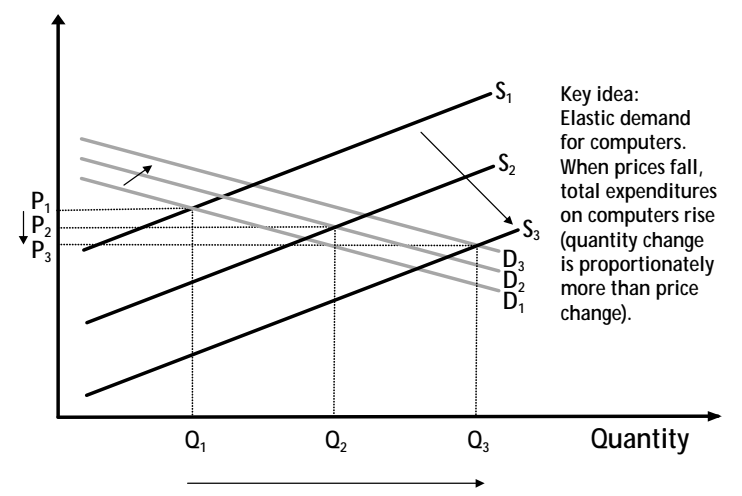

computer demand curve is shifting rapidly to the right, as income rises. Unlike the demand for agricultural products, the computer demand curve has a relatively flat slope (see Figure 7). Business demand for computers is rising rapidly, of course, because computers so enhance the productivity of production processes of all sorts of goods, including agricultural goods, and because of falling prices of computer goods. In fact, it seems likely that the vast increase in the use of computers has contributed significantly to the acceleration in nonfarm labor productivity growth.
Thus, rising real personal incomes and increasing business use of computers propel the computer demand curve outward, and declining computer prices driven by the outward shift in supply stimulates higher purchases as we slide down the relatively flat demand curve. The outcome, as seen in Figure 7, is that computer production is exploding. Since 1959, output of computer and office equipment has increased at an average annual rate of 21 percent per year, whereas total factory output and real GDP both rose only about 3.5 percent per year. Now, if only farmers could find a way to stimulate demand for a bushel of corn on every desktop!

\section{MONETARY POLICY AND AGRICULTURE}

From time to time, every central bank finds that it must change interest rates to maintain low and steady inflation. Let's take a moment to understand why.

Suppose there were some way for the central bank to achieve low inflation without acting directly on interest rates. For example, suppose the central bank controlled money growth directly-indeed, there is an extensive literature arguing that this policy is the one central banks should pursue ${ }^{14}$ The Federal Reserve might raise and lower money growth as needed to achieve its objective of low and steady inflation. Interest rates would fluctuate freely in the marketplace. Even when the Fed maintained rock steady money growth, interest rates might rise or fall. In particular, when the economy boomed, rates would tend to rise as households and firms bid for funds to finance spending on new investment, houses, cars, and all the other things people commonly finance by borrowing. Similarly, when the economy slowed, interest rates would tend to fall, even if the Fed did nothing but maintain steady money growth.

A strong economy tends to push interest rates up and a weak economy tends to push interest rates down, this is illustrated nicely by the recent Japanese experience. Most are aware that Japanese growth has been somewhere between anemic and nonexistent for a good number of years. In fact, since the fourth quarter of 1991, Japanese real GDP has grown at an average rate of only 0.7 percent per year. Since the fourth quarter of 1996, Japanese output has actually declined at about a 1.25 percent annual rate. Meanwhile, interest rates on short-term Japanese

\footnotetext{
${ }^{14}$ For example, see Cagan (1989).
} 
government securities have been at or near zero percent for the last year, and still the economy continues to stumble along.

The Federal Reserve, along with almost all other central banks, conducts monetary policy by adjusting its target for the interest rate on shortterm interbank borrowing, known in the United States as the federal funds rate. The Fed calls this target the intended federal funds rate. What the Fed tries to do is to mimic, in broad outline, how the federal funds rate would fluctuate if the Fed could set the rate of inflation directly, or through some other policy tool such as money growth. If the Fed fails to adjust the intended federal funds rate appropriately, it will fail in its mission to achieve low and steady inflation.

When the Fed raises the intended federal funds rate, other interest rates typically follow. In fact, other rates not infrequently lead the intended rate, as the market anticipates what the Fed is going to do. Almost everyone who has borrowed funds using short-maturity loans-and, therefore, expects to pay higher rates on those borrowings in the future-everyone in the process of borrowing funds, and everyone thinking about borrowing in the future feels hurt by the increase in interest rates. And since almost everyone in the country either has borrowed, is in the process of borrowing, or expects to borrow in the future, this means that there is al most universal pain whenever interest rates rise.

But what is the choice? If interest rates don't rise in a timely fashion, then sooner or later inflation will begin to rise. When that happens, investors will put additional upward pressure on interest rates, to protect their capital from being eroded by inflation. So, a central bank that delays raising rates does not, in the end, avoid rate increases, but, instead, imposes both higher inflation and, eventually, even higher interest rates on society.

Because the lessons that flow from procrastination in monetary policy were learned so painfully during the 1970s, and because Fed policy has been so successful since 1982, when the inflation of the 1970s was finally conquered, complaints about periods during which interest rates rise have been relatively muted. Still, when interest rates rise, farmers, agricultural implement manufacturers and dealers, and other related businesses often complain. So also do home builders, whose industry is especially interest-sensitive, car manufacturers and dealers, and many others. And while the Federal Open Market Committee (FOMC) takes these con- siderations into account during its deliberations, at the end of the day policy must be made on what is best for the country as a whole.

Sometimes, to push this reasoning further, the argument is a bit different. When agriculture, or any other industry, is going through a difficult period, pleas for assistance are understandable. Why can't the Fed lower interest rates to help in such situations? For example, when the Asian economic crisis hit in mid-1997, U.S. agricultural exports were especially hard hit. The crisis deepened in mid-1998 with the Russian default. The Fed did lower interest rates in the fall of 1998, to prevent the financial disruption from spilling over to affect the stability of the U.S. economy. As financial conditions returned to normal last year, the Fed raised the intended fed funds rate, and market rates rose as well. But the effects of the Asian problems on the farm economy lingered, and continue to linger to this day. In 1999, exports of agricultural commodities in nominal terms declined for the third year in a row, and were down 20 percent from their 1996 peak of $\$ 60.4$ billion.

Now, we're not suggesting that Fed policy should be unaccountable. Indeed, Fed policy should be examined and reexamined continuously in vigorous public debate, and it is. The Fed needs to defend and explain its policy decisions, and all senior Federal Reserve officials contribute to that process in innumerable ways.

Many people do not understand, however, that as powerful as monetary policy is, a central bank has essentially only one policy instrument. I like to think of that instrument as the rate of money growth-or, more generally, the provision of liquidity to the economy-over the long run. In the short run, the Fed implements its control over the growth of liquidity by setting the intended federal funds rate. With only one policy instrument, the central bank can at best achieve only one policy objective $^{15}$ That objective is a low and stable rate of inflation. If the Fed tries to pursue other objectives, it may lose control over the rate of inflation.

Our experience during the 1970s drove home with stark clarity the consequences of losing control over the rate of inflation. The economy suffered from high and unstable interest rates, rapid swings in the international value of the dollar and increased

\footnotetext{
${ }^{15}$ See Poole (2000) for a discussion of the limitations of monetary policy in this regard.
} 
instability of employment and output. The recessions of 1973-75 and 1981-82 were among the most severe downturns in U.S. history. The instabilities of this period added to the burdens suffered by agriculture, homebuilders, and other industries.

The U.S. economy is dynamic and rapidly changing. At any given time, certain industrial and geographic sectors are bound to lag the overall economy, while others do better than the overall economy. Monetary policy can do little to help the lagging sectors - there are no policy instruments at the Fed's disposal that have sector-specific effects. With respect to agriculture, in particular, economic research generally shows that monetary policy actions have no significant effects on relative agricultural prices. $^{16}$ The Fed's responsibility is to maintain low and stable inflation and - to the extent possible within this basic objective - to smooth temporary disturbances.

\section{A FINAL WORD}

The main message of this article is simple: U.S. agriculture is a spectacular success story of high productivity growth maintained over an amazingly long period of time Most U.S. success stories can be characterized as enjoying a period of rapid growth and innovation followed in a relatively few years by a mature stage of slow growth. Think of railroads, automobiles, and steel. U.S. agriculture, on the other hand, is characterized even today by exciting gains in productivity; yet, it is not a mature industry. Nevertheless, the industry today suffers from the same problems it has always suffered from: droughts, locusts, and market disruptions. It is a risky enterprise, and anyone who really understands the economies of agriculture can only have great respect for those who cope and prosper in this business.

The contribution monetary policy can make to agriculture is quite simple: to maintain low and steady inflation. Farmers, ranchers, and policymakers of all stripes should not underestimate the importance of agriculture to a stable overall U.S. economy. Low inflation, stable inflation expectations, relatively low interest rates on the average, high, and stable employment, all contribute to stability of the agricultural economy. The reality is that the fundamental economic forces controlling the destiny of agriculture - high productivity growth, the hazards of nature, the low price and income elasticities of demand, and the instability of conditions in important export mar- kets-are things that the Fed can do nothing about. But the Fed can help to maintain a stable domestic economy. If the Fed can continue to be successful in tempering that important historical source of instability to U.S. agriculture, it will have done its job well.

\section{REFERENCES}

Belongia, Michael T. "The Farm Sector in the 1980s: Sudden Collapse or Steady Downturn?" this Review (November 1986), pp. 17-25.

"Monetary Policy and the Farm/Nonfarm Price Ratio: A Comparison of Effects in Alternative Models," this Review (July/August 1991), pp. 30-46.

Cagan, Phillip. "Money-Income Causality-A Critical Review of the Literature Since A Monetary History," in Money, History and International Finance: Essays in Honor of Anna J. Schwartz. Michael D. Bordo (ed.), University of Chicago Press, 1989, pp. 117-51.

Council of Economic Advisers. Economic Report of the President, United States Government Printing Office (February 2000).

Francis, Darryl R. "Impact of Monetary Actions on Farm Income and Finance," American Journal of Agricultural Economics (December 1974), pp. 1047-55.

Gardner, Bruce L. “Changing Economic Perspectives on the Farm Problem," Journal of Economic Literature (March 1992), pp. 62-101.

Houthakker, Hendrik. "Economic Policy for the Farm Sector," American Enterprise Institute, Washington, DC (1967).

Isaac, Alan G., and David E. Rapach. "Monetary Shocks and Relative Farm Prices: A Re-examination," American Journal of Agricultural Economics (November 1997), pp. 1332-39.

Poole, William. "Great Monetary Myths," speech to the Great Issues Series sponsored by St. Louis University, February 24, 2000.

, and Howard J. Wall. "Price Stability and

the Rising Tide: How Low Inflation Lifts All Ships," The Regional Economist, Federal Reserve Bank of St. Louis (January 2000), pp. 5-9.

Taylor, John B. "Monetary Policy and the Long Boom," this Review (November/December 1998), pp. 3-11.

United States Department of the Census. Historical Statistics of the United States, 1790 to 1970 (Government Printing Office, 1978).

${ }^{16}$ See Belongia (1991) or Isaac and Rapach (1997). 